\title{
COVID-19 infection as a systemic disease
}

\author{
Marco Bongiovanni* and Alessandro Maria Marra \\ Internal Medicine Unit, Department of Medicine, Ospedale di Circolo di Rho, ASST Rhodense Milan, Italy
}

\begin{abstract}
The pandemic caused by COVID-19 infection has had a dramatic impact on Health care systems throughout the World. Several issues concerning this disease are still unknown; in particular the involvement of extra-pulmonary tissues and how this might affect prognosis of COVID-19 infected individuals remains still debated. Further, healthcare workers should be aware of the possible atypical presentations of COVID-19 infection in order to promptly implement the appropriate measures to contain the transmission of the disease. As a consequence, all the people involved in the management of the pandemic should go beyond simply considering COVID-19 infection as a lung disease with theoretical involvement of other organs, but they should start considering it a systemic disease with major pulmonary involvement. This change of perspective would probably allow a better understanding of the clinical, pathophysiological and therapeutic characteristics of COVID-19 infection.
\end{abstract}

\section{Introduction}

The coronavirus SARS-CoV-2 (severe acute respiratory syndrome coronavirus 2) which is responsible for the disease COVID-19 (coronavirus disease 2019) has infected at the moment over 30 million people and has caused more than 950000 deaths globally. The infection developed at first in Wuhan, the capital of Hubei province, China, at the end of 2019 [1,2] from where it rapidly spread throughout China. From China, infection rapidly reached Europe, USA and South America, with the number of new cases currently increasing every day [3-5]. The World Health Organization declared the coronavirus diseases 2019 (COVID-19) as a pandemic due to its widespread infectivity and high contagion rate [6].

The clinical features of coronavirus infection vary widely, from asymptomatic infection to severe pneumonia with acute respiratory failure and even death [2,7]. In particular, most of subjects develop mild to moderate disease, $10-15 \%$ have severe disease and approximately 4-6\% have critical disease requiring admission to intensive care unit [8]. Elderly patients with underlying chronic diseases such as diabetes or cardiovascular conditions seem to be more vulnerable to severe diseases and death $[9,10]$. Most typical symptoms of COVID-19 infection include fever, dry cough, sore throat, fatigue, dyspnea and myalgia [2]. However, several other features have been reported quite frequently, such as nausea, anosmia, dysgeusia, vomiting and diarrhea. These symptoms may occur at the onset of the disease or immediately thereafter. Clinical experience and the emerging literature suggest that several organs and systems can all be affected by COVID-19 infection, with a different degree of severity [11-16]. It's therefore mandatory for healthcare workers to be aware of the possibility of COVID-19 presenting with non-specific symptoms; this is crucial to ensure early diagnosis and finally reduce the risk of transmission. The objective of this review is to describe the most frequent extrapulmonary presentations of COVID-19 infection, in order to consider this infection as a systemic disease.

\section{Pathophysiology}

The multi-organ involvement often observed in subjects with COVID-19 infection may be a consequence of either extrapulmonary dissemination and replication of SARS-CoV-2, as occurred for other coronaviruses [17], or of the immune-pathological sequelae of the disease. In particular, SARS-CoV-2 can bind angiotensin converting enzymes 2 (ACE2) receptors that are usually expressed in multiple extrapulmonary tissues [18-20] and this can lead to a direct viral tissue damage. This hypothesis is supported by the evidence that the viral RNA of SARS-CoV-2 has been isolated from fecal samples and, even if less commonly, from urine and blood [21-23]. Different histo-pathological studies have demonstrated a specific tropism of SARS-CoV-2 for renal, myocardial, neurological, gastrointestinal and pharyngeal tissues [22,24-26]. However, it is still to be determined whether the spread of SARS-CoV-2 infection to extrapulmonary tissues can occur by haematogenic or by other routes.

Mechanisms at the basis of the multi-organ damage secondary to SARS-CoV-2 infection may include the endothelial cell damage secondary to thrombo-inflammation and the dysregulation of the immune response and of the renin-angiotensin-aldosterone system. The endothelial damage could be also mediated by the expression of ACE2 receptors in arterial and venous endothelium of several organs $[27,28]$. Endothelial injuries associated with COVID-19 infection can trigger excessive thrombin production, inhibit fibrinolysis, and finally activate the complement pathways leading to micro-thrombi deposition and microvascular abnormalities [28,29].

Severe COVID-19 disease is usually associated with an altered immune response with secondary cytokine-release syndrome due to a hyper-activation of innate immunity [30]; rapid viral replication, antagonism of interferon signaling and activation of neutrophils and monocyte-macrophages as mediators of inflammation have been proposed as mechanism at the basis of this phenomenon [31,32].

${ }^{\star}$ Correspondence to: Marco Bongiovanni, $\mathrm{MD}, \mathrm{PhD}$, Internal Medicine Unit, Department of Medicine, Ospedale di Circolo di Rho, ASST Rhodense, Milan, Italy, Tel: +39 3335895304; E-mail: mbongiovanni@asst-rhodense.it

Received: November 17, 2020; Accepted: January 11, 2021; Published: January 14,2021 
According to these observations, the elevation of serum inflammatory markers (such as C-reactive protein, $\mathrm{D}$-dimer, lactate dehydrogenase, procalcitonin) has been associated with an unfavorable outcome $[9,33,34]$, as were high levels of the cytokine IL-6 in the serum [35].

At the moment, no definitive data are available on the relative importance of these mechanism as part of the pathophysiology of COVID-19 infection; in particular, although tissue damage and the alterations of the renin-angiotensin-aldosterone system could be exclusive of SARS-CoV-2, the dysregulation of immune response and the damages to microcirculation are often observed also as a consequence of the systemic release of cytokine in patients with bacterial sepsis [36].

\section{Cardiovascular manifestations}

A large amount of reports described cardiovascular symptoms and diseases in patients with COVID-19 infection, including myocardial infarction, acute coronary syndrome, cardiomyopathy, arrhythmias and cardiogenic shock [37,38]. Myocardial injury occurred in more than $20 \%$ of hospitalized patients with COVID-19, especially in those with pre-existing cardiovascular diseases; the level of increase in troponin values has been correlated with an unfavorable outcome [39]. A case series including 18 patients presented with ST segment elevation on ECG showed that 6 patients had coronary obstruction leading to myocardial infarction, 2 were diagnosed with myocardial infarction through discover of wall abnormalities on echocardiogram and 10 had non-coronary myocardial injury; in these cohort, D-dimer levels were higher in subjects diagnosed with myocardial infarction compared to others, underlying the prognostic value of this parameter [40]. Cardiac arrhythmias, mainly new-onset atrial fibrillation but also heart block and ventricular arrhythmias, have been frequently reported during COVID-19 disease; ranging from $17 \%$ among hospitalized patients and $44 \%$ among those admitted in intensive care units (2). Another report demonstrated that atrial arrhythmias were more common in patients underwent to mechanical ventilation [41]. Inflammation of the cardiac wall leading to myocarditis, pericarditis and pericardial effusion is often observed during the course of viral infections, such as flu. Some case reports described the occurrence of myocarditis as the first manifestation of COVID-19 infection, highlighting the importance of recognize cardiac symptoms as possible presentation of the COVID-19 disease even in absence of respiratory symptoms or radiological features of interstitial pneumonia $[42,43]$.

\section{Thrombotic manifestations}

There are multiple evidences on the hypercoagulable state of COVID-19 infected subjects; as a consequence, an increased level of D-dimer, fibrinogen and antiphospolipid antibodies is often observed in this population $[44,45]$. Thrombotic complications were initially reported in up to $30 \%$ of patients admitted to intensive care unit $[46,47]$. Other reports described the development of thrombosis in intravenous catheters and extracorporeal circuits, as well as arterial vascular occlusive events, as stroke and acute limb ischemia, even in patients who received prophylactic anticoagulation [48-49]; the occurrence of these events seems more frequent in subjects with severe disease [50-52]. Further, the rates of pulmonary embolism is significantly higher in COVID-19 infected patients [53,54]; in particular, when routinely screened for thrombotic diseases, COVID-19 infected individuals had a high rates of thrombotic complications, despite the use of thromboprophylaxis $[55,56]$. The differences observed in the published studies are probably due to heterogeneity of the screening and to the thromboprophylaxis schedules used. As a consequence, it is very important for health care workers to be aware of the possible association between COVID-19 infection and thrombotic events, especially in those patients admitted to the hospital for thrombotic events without known risk factors for thromboembolism.

\section{Neurological manifestations}

Multiple neurological manifestations have been described in subjects with COVID-19 infection. Also, several non-specific neurological symptoms have been frequently reported in this population such as dizziness, headache, myalgia/fatigue and anorexia [2,7]. An analysis on 214 patients with severe COVID-19 infection showed that $36 \%$ of these subjects had neurological symptoms [57]. Further, some patients presented with acute stroke or impaired consciousness and altered mental status $[49,57]$ especially in the first 14 days following intensive care unit, confirming the need of thromboprohylaxis in all COVID-19 infected patients with severe disease. In addition, cases of Guillain-Barrè syndrome, meningoencephalitis, hemorrhagic posterior reversible encephalopathy syndrome and acute necrotizing encephalopathy have been reported [48,58-61]. The guidelines drawn up during COVID-19 pandemic underlying the need for maintaining an adequate adherence to established guidelines for the management of acute stroke, including the early access to thrombolysis and thrombectomy; nevertheless, the post-acute care management should be modified according to the pandemic constraints $[62,63]$.

\section{Olfactory, taste and ophthalmological manifestations}

Both olfactory and taste abnormalities have been reported as presenting symptoms of COVID-19 infection. These symptoms may precede or may be associated with other typical symptoms of COVID-19 or, sometimes, may also occur in isolation. A large study on 417 patients with mild to moderate COVID-19 infection reported that $85 \%$ of patients had smell or taste abnormalities; in particular in a fair number of subjects smell dysfunctions preceded the onset of typical symptoms of COVID-19 infection [64]. In another survey on a large population, anosmia was the only symptom reported in $17 \%$ of patients diagnosed with SARS-CoV-2 [65]. As a consequence, the development of anosmia might be used as a screening tool to identify and isolate the asymptomatic carriers, drastically reducing the risk of transmission of the infection. According to this, during the pandemic period all the patients with new onset of anosmia or smell abnormalities should be tested for SARS-CoV-2.

The main reported ocular manifestation in patients with COVID-19 is conjunctivitis. Usually, this symptom occurs in association with other features of COVID-19 infection but only rarely is the initial symptom; however, more than $30 \%$ of patients with COVID-19 infection have clinical signs of conjunctivitis, especially those with more severe disease [66]. Finally, the presence of SARS-CoV-2 in tears and conjunctival secretions may raise questions about the possible transmission of COVID-19 infection by tears and underline the importance of using eye protection by healthcare workers.

\section{Gastrointestinal manifestations}

Anorexia, diarrhea, nausea, vomiting and abdominal pain are the most frequently reported gastrointestinal manifestations in patients with COVID-19 infection, with their specific prevalence ranging widely across the studies [67-70]. Gastrointestinal symptoms may be associated with a longer duration of disease and with a delayed admission to the hospital but have not been associated with increased mortality $[67,70]$. 
Therefore, COVID-19 infection should be considered as a differential diagnosis even in absence of respiratory symptoms, and patients presenting with diarrhea or nausea or vomiting should be rapidly tested for SARS-CoV-2 to make early diagnosis feasible.

\section{Hepatobiliary manifestations}

Signs of hepatobiliary damage are often observed in subjects with COVID-19 infection, with range $14-53 \%$ in different case studies, especially in patients with severe disease $[11,12,71,72]$. Aminotransferases are typically elevated, but usually remain less than 5 times the upper limit of normal; cases of self-limited acute hepatitis have been occasionally reported [73,74]. In a recent meta-analysis, the pooled prevalence of liver function abnormalities was 19\% [70] and these findings correlated with disease severity. In particular, it has been demonstrated that SARS-CoV-2 infection in the liver directly contributes to hepatic impairment in patients with COVID-19 pneumonia. Also bilirubin elevation has been associated with disease severity and bilirubin level has been also included in a validated clinical risk score to predict disease progression $[75,76]$. Liver test abnormalities in COVID-19 infected individuals may be due to several factors, such as myositis, cardiac injuries (if compatible symptoms), ischemia, cytokine-release syndrome and co-infection with other hepatotropic viruses as well as a direct role of SARS-CoV-2 itself [77]. Prospective monitoring of liver enzyme is therefore recommended, particularly in those patients who received investigational drugs as remdesevir, tocilizumab or other antivirals.

\section{Renal manifestations}

A significant amount of COVID-19 infected individuals develop a severe kidney damage during the acute phase of disease, leading to an increased risk of mortality [78,79]. Usually, renal failure occurs rapidly after admission and involves more than $30 \%$ of COVID-19 infected patients, with $14 \%$ of them requiring dialysis treatment [80]; the rate of acute kidney damage is strictly associated with disease severity, occurring up to $90 \%$ of critically ill patients [81]. Further, both hematuria and proteinuria have been reported in patients with severe COVID-19 infection, as were hyperkalemia and acidosis $(35,80)$. Kidney function should be carefully tested at admission in patients with COVID-19 infection, because this could help in early stratifying the risk of disease progression $[79,82]$. Additionally, the Surviving Sepsis guidelines on coronavirus recommend a conservative fluid resuscitation strategy in COVID-19 infected individuals to avoid hypervolemia which could worsen respiratory compensation [83]. In this specific setting, a dramatic increase in the need for renal replacement therapy should be expected. Further, the prothrombotic action of SARS-CoV-2 may represent a risk for circuit clotting in this patients; therefore, in the absence of contraindication, an anticoagulation strategy should be considered [84].

\section{Dermatologic manifestations}

Cutaneous features have been occasionally described in patients with COVID-19 infection. An observational study found a frequency of $20 \%$ of dermatologic manifestations in patients hospitalized for COVID-19 infection, without correlation with disease severity [85]. The cutaneous findings more often observed are erythematous rash, urticarial and chickenpox-like vesicles. A systematic review found that acro-cutaneous lesions are the most common reported skin findings [86]. Another cross-sectional study found that chilblain-like lesions were associated with less severe disease compared to livedoid or necrotic lesions [16]. Finally, several report assessed a significant rate of alopecia in COVID-19 infected individuals, likely androgen-mediated [87]. Most of cutaneous manifestations of COVID-19 infection are usually self-resolving; however, it is still debated if patients with underlying dermatologic diseases and COVID-19 infection have an augmented risk of cutaneous complications.

\section{Reproductive system}

There is a growing concern regarding the impact of COVID-19 infection on male reproductive function. SARS-CoV-2 may cause direct testicular damage through binding with testicular ACE2 receptors which are highly expressed in the tests; further, the testicular damage may be secondary to induction of testicular inflammation and immune response $[88,89]$. A study demonstrated that male patients affected by COVID-19 infection have low testosterone level, high luteinizing hormone $(\mathrm{LH})$ and low testosterone/ $\mathrm{LH}$ ratio, indicating a possible damage of Leydig cells function [90]. At the moment, it is not clear whether fertility dysfunction is permanent or not; it has been reported that low sperm concentration with low motility is present up to three months after SARS-CoV-2 infection [91], but, at the moment, a longer follow-up is not available.

\section{Psychiatric manifestations}

Mental health issues in COVID-19 infected subjects have been evaluated in different case series. Levels of post-traumatic stress symptoms were significantly higher among patients hospitalized for COVID-19 infection (96.2\%) compared to the general population (7\%), as was the risk for depression [92-94]. It's well known that infections are associated with a higher risk of mood disorders; in the past, patients affected by SARS-CoV-1 developed depressive symptoms during the epidemic [95]. The similar findings observed also for SARS-CoV-2 could be due to a direct action of coronavirus on the brain or also to an indirect action induced by a massive cytokine response that involves the brain [96]. At the moment, very scarce data are available on the COVID-19 infection impact on patients with pre-existing psychiatric disorders, but it seems likely a worsening of the underlined symptoms also in this population [97]. Despite an increase of psychiatric disorders in patients hospitalized for COVID-19 infection during the acute phase of disease, the long-term probability of persistence of these disorders remains unknown.

\section{Conclusion}

An increasing number of reports have shown the systemic and multi-organ localization of COVID-19 infection. These findings allow us to hypothesize that COVID-19 infection is a systemic disease without prejudice to the well-known, life-threatening pulmonary complications. Therefore, it seem imperative a comprehensive understanding of the common and organ-specific manifestations of this systemic disease in order to test and eventually isolate the patients as soon as possible, avoiding the widespread transmission of the disease secondary to a delayed diagnosis. Further, several aspects of this disease are still unexplained. Why do some patients develop some symptoms and other patients don't? Why are some disease localization associated with a better prognosis than others? At the moment, there are no definite answers for both of these questions. Probably, if we begin to consider COVID-19 infection as a systemic disease, we will be able to understand it better.

\section{References}

1. Chan JF-W, Yuan S, Kok K-H, To KK, Chu H, et al. (2020) A familial cluster of pneumonia associated with the 2019 novel coronavirus indicating person-to-person transmission: a study of a family cluster. Lancet 395: 514-23. 
2. Wang D, Hu B, Hu C, Zhu F, Liu X, et al. (2020) Clinical characteristics of 138 hospitalized patients with 2019 novel coronavirus-infected-pneumonia in Wuhan, China. JAMA 323: 1061-1069. [Crossref]

3. Rothe C, Schunk M, Sothmann P, Bretzel G, Froeschl G, et al. (2020) Transmission of SARS-CoV-2 infection from an asymptomatic contact in Germany. N Engl J Med 382: 970-971. [Crossref]

4. Holshue ML, DeBolt C, Lindquist S, Lofy KH, Wiesman J, et al. (2020) First case of 2019 novel coronavirus in the United States. $N$ Engl J Med 382: 929-936. [Crossref]

5. Remuzzi A, Remuzzi G (2020) COVID-19 and Italy: what next? Lancet 395: 12251228.

6. Mahase E (2020) Covid-19: WHO declares pandemic because of "alarming levels" of spread, severity, and inaction. BMJ 368: m1036. [Crossref]

7. Huang C, Wang Y, Li X, Ren L, Zhao J, et al. (2020) Clinical features of patients infected with 2019 novel coronavirus in Wuhan, China. Lancet 395: 497-506. [Crossref]

8. Wu Z, McGoogan JM (2020) Characteristics of and important lessons from the Coronavirus Disease 2019 (COVID-19) outbreak in China: summary of a report of 72314 cases from the Chinese Center for Disease Control and Prevention. JAMA 323: 1239-1242. [Crossref]

9. Bongiovanni M, De Lauretis A, Manes G, Marra AM, Bodini BD, et al. (2020) Clinical characteristics and outcome of COVID-19 pneumonia in elderly subjects. $J$ Infect 19 : S0163-4453. [Crossref]

10. Lian J, Jin X, Hao S, Cai H, Zhang S, et al. (2020) Analysis of epidemiological and clinical features in older patients with Coronavirus Disease 2019 (COVID-19) outside Wuhan. Clin Infect Dis 71: 740-747. [Crossref]

11. Guan WJ, Ni ZY, Hu Y, Liang WH, Ou CQ, et al. (2020) Clinical characteristics of coronavirus disease 2019 in China. N Engl J Med 382: 1708-20. [Crossref]

12. Shi S, Qin M, Cai Y, Liu T, Shen B, et al. (2020) Characteristics and clinical significance of myocardial injury in patients with severe coronavirus disease 2019. Eur Heart J 41: 2070-2079. [Crossref]

13. Tan CW, Low JGH, wong WH, Chua YY, Goh SL, et al. (2020) Critically ill COVID-19 infected patients exhibits increased clot wavefrom analysis parameters consistent with hypercoagulability. Am J Hematol 95: E156-E158. [Crossref]

14. Cai Q, Huang D, Yu H, Zhu Z, Xia Z, et al. (2020) COVID-19: abnormal liver function tests. J Hepatol 73: 566-574. [Crossref]

15. Asadi-Pooya AA, Simani L (2020) Central nervous system manifestations of COVID-19: a systematic review. J Neurol Sci 413: 116832. [Crossref]

16. Galvan-Casas C, Català A, Carretero Hernandez G, Rodriguez-Jimenez P, FernandezNieto D, et al. (2020) Classification of the cutaneous manifestations of COVID-19: a rapid prospective nationwide consensus study in Spain with 375 cases. $\mathrm{Br} J$ Dermatol 183: 71-77. [Crossref]

17. Holmes KV (2003) SARS coronavirus: a new challenge for prevention and therapy. $J$ Clin Invest 111: 1605-1609. [Crossref]

18. Lan J, Ge J, Yu J, Shan S, Zhou H, et al. (2020) Structure of the SARS-CoV-2 spike receptor-binding domain bound to the ACE2 receptor. Nature 581: 215-220. [Crossref]

19. Shang J, Ye G, Shi K, Wan Y, Luo C, et al. (2020) Structural basis of receptor recognition by SARS-CoV-2. Nature 581: 221-224. [Crossref]

20. Gupta A, Madhavan MV, Sehgal K, Nair N, Mahajan S, et al. (2020) Extrapulmonary manifestation of COVID-19. Nat Med 26: 1017-1032. [Crossref]

21. Wolfel R, Corman VM, Guggemos W, Seilmaier M, Zange S, et al. (2020) Virologica assessment of hospitalized patients with COVID-2019. Nature 581: 465-469. [Crossref]

22. Puelles VG, Lutgehetmann M, Lindenmeyer MT, Sperhake JP, Wong MN, et al. (2020) Multiorgan and renal tropism of SARS-CoV-2. N Eng J Med 383: 590-592. [Crossref]

23. Wang W, Xu Y, Gao R, Lu R, Han K, et al. (2020) Detection of SARS-CoV-2 in different types of clinical specimens. JAMA 323: 1843-1844. [Crossref]

24. Su H, Yang M, Wan C, Yi LX, Tang F, et al. (2020) Renal histopathological analysis of 26 postmortem findings of patients with COVID-19 in China. Kidney Int 98: 219227. [Crossref]

25. Tavazzi G, Pellegrini C, Maurelli M, Belliato M, Sciutti F, et al. (2020) Myocardia localization of coronavirus in COVID-19 cardiogenic shock. Eur J Heart Fail 22: 911 915. [Crossref]

26. Xiao F, Tang M, Zheng X, Liu Y, Li X, et al. (2020) Evidence for gastrointestinal infection of SARS-CoV-2. Gastroenterology 158: 1831-33e3. [Crossref]
27. Hamming I, Timens W, Bulthius MLC, Lely AT, Navis GJ, et al. (2004) Tissue distribution of ACE2 protein, the functional receptor for SARS coronavirus. A first step in understanding SARS pathogenesis. J Pathol 203: 631-637. [Crossref]

28. Varga Z, Flammer AJ, Steiger P, Haberecker M, Andermatt R, et al. (2020) Endothelial cell infection and endothelitis in COVID-19. Lancet 395: 1417-1418. [Crossref]

29. Bikdeli B, Madhavan MV, Gupta A, Jimenez D, Burton JR, et al. (2020) Pharmacological agents targeting thromboinflammation in COVID-19: review and implications for future research. Thromb Haemost 120: 1004-1024. [Crossref]

30. Kim KD, Zhao J, Auh S, Yang X, Du P, et al. (2007) Adaptive immune cells temper initial innate response. Nat Med 13: 1248-1252. [Crossref]

31. Ye Q, Wang B, Mao J (2020) The pathogenesis and treatment of the "Cytokine Storm" in COVID-19. J Infect 80: 607-613. [Crossref]

32. Huang KJ, Su IJ, Theron M, Wu YC, Lai SK, et al. (2005) An interferon- $\gamma$-related cytokine storm in SARS patients. J Med Virol 75: 185-194. [Crossref]

33. Zhou F, Yu T, Du R, Fan G, Liu Y, et al. (2020) Clinical course and risk factors for mortality of adult inpatients with COVID-19 in Wuhan, China: a retrospective cohort study. Lancet 395:1054-1062. [Crossref]

34. Wu C, Chen X, Cai Y, Xia J, Zhou X, et al. (2020) Risk factors associated with acute respiratory distress syndrome and death in patients with coronavirus disease 2019 pneumonia in Wuhan, China. JAMA 180: 934-943. [Crossref]

35. Cummings MJ, Baldwin MR, Abrams D, Jacobson SD, Meyer BJ, et al. (2020) Epidemiology, clinical course, and outcome of critically ill adults with COVID-19 in New York City: a prospective cohort study. Lancet 395:1763-1770. [Crossref]

36. Li H, Liu L, Zhang D, Xu J, Dai H, et al. (2020) SARS-CoV-2 and viral sepsis observations and hypotheses. Lancet 395: 1517-1520. [Crossref]

37. Driggin E, Madhavan MD, Bikdeli B, Chuich T, Laracy J, et al. (2020) Cardiovascular considerations for patients, health care workers, and health systems during the coronavirus disease 2019 (COVID-19) pandemic. J Am Coll Cardiol 75: 2352-2371. [Crossref]

38. Clerkin KJ, Fried JA, Raikhelkar J, Sayer G, Griffin JM, et al. (2020) COVID-19 and cardiovascular disease. Circulation 141: 1648-1655. [Crossref]

39. Guo T, Fan Y, Chen M, Wu X, Zhang L, et al (2020) Cardiovascular implications of fatal outcomes of patients with coronavirus disease 2019 (COVID-19). JAMA Cardiol 5: 811-818. [Crossref]

40. Bangalore S, Sharma A, Slotwiner A, Yatskar L, Harari R, et al. (2020) ST-segment elevation in patients with COVID-19-A case series. $N$ Engl J Med 382: 2478-2480. [Crossref]

41. Goyal P, Choi JJ, Pinheiro LC, Schenck EJ, Chen R, et al. (2020) Clinical characteristics of COVID-19 in New York City. N Engl J Med 382: 2372-2374. [Crossref]

42. Inciardi RM, Lupi L, Zaccone G, Italia L, Raffo M, et al. (2020) Cardiac involvement in a patient with coronavirus disease 2019 (COVID-19). JAMA Cardiol 5: 819-824. [Crossref]

43. Doyen D, Moceri P, Ducreux D, Dellamonica J (2020) Myocarditis in a patient with COVID-19: a cause of raised troponin and ECG changes. Lancet 395: 1516. [Crossref]

44. Han H, Yang L, Liu R, Liu F, Wu K, et al. (2020) Prominent changes in blood coagulation of patients with SARS-CoV-2 infection. Clin Chem Lab Med 58: 11161120. [Crossref]

45. Zhang Y, Xiao M, Zhang S, Xia P, Cao W, et al. (2020) Coagulopathy and antiphospholipid antibodies in patients with COVID-19. N Engl J Med 382: e38 [Crossref]

46. Cui S, Chen S, Li X, Liu S, Wang F (2020) Prevalence of venous thromboembolism in patients with severe novel coronavirus pneumonia. J Thromb Haemost 18: 1421-1424. [Crossref]

47. Klok FA, Kruip MJHA, van der Meer NJM, Arbous MS, Gommers DAMPJ, et al. (2020) Incidence of thrombotic complications in critically ill ICU patients with COVID-19. Thromb Res 191: 145-147. [Crossref]

48. Llitjos JF, Leclerc M, Chochois C, Monsallier JM, Ramakers M, et al. (2020) High incidence of venous thromboembolism events in anticoagulated severe COVID-19 patients. J Thromb Haemost 18: 1743-1746. [Crossref]

49. Lodigiani C, Iapichino G, Carenzo L, Cecconi M, Ferrazzi P, et al. (2020) Venous and arterial thromboembolic complications in COVID-19 patients admitted to an academic hospital in Milan, Italy. $J$ Thromb Res 191: 9-14. [Crossref] 
50. Helms J, Kremer S, Merdji H, Clere-Jehl R, Schenck M, et al. (2020) Neurological features in severe SARS-CoV-2 infection. $N$ Engl J Med 382: 2268-2270. [Crossref]

51. Oxley TJ, Mocco J, Majidi S, Kellner CP, Shoirah H, et al. (2020) Large-vessel stroke as a presenting feature of COVID-19 in the young. N Engl J Med 382: e60. [Crossref]

52. Perini P, Nabulsi B, Massoni C, Azzarone M, Freyrie A (2020) Acute limb ischemia in two young, non-atherosclerotic patients with COVID-19. Lancet 395: 1546. [Crossref]

53. Casey K, Iteen A, Nicolini R, Auten G (2020) COVID-19 pneumonia with haemoptysis: acute segmental pulmonary emboli associated with novel coronavirus infection. Am J Emerg Med 38: 1544e1-1544e3. [Crossref]

54. Poissy J, Goutay J, Caplan M, Parmentier E, Duburcq T, et al. (2020) Pulmonary embolism in COVID-19 patients: awareness of an increased prevalence. Circulation 142: 184-186. [Crossref]

55. Nahum J, Morichau-Beauchant T, Daviaud F, Echegut P, Fichet J, et al. (2020) Venous thrombosis among critically ill patients with coronavirus disease 2019 (COVID-19). JAMA Netw Open 3: e2010478. [Crossref]

56. Ren B, Yan F, Deng Z, Zhang S, Xiao L, et al. (2020) Extremely high incidence of lower extremity deep venous thrombosis in 48 patients with severe COVID-19 in Wuhan. Circulation 142: 181-183. [Crossref]

57. Mao L, Jin H, Wang M, Hu Y, Chen S, et al. (2020) Neurologic manifestations of hospitalized patients with coronavirus disease 2019 in Wuhan, China. JAMA Neurol 77: 683-690. [Crossref]

58. Toscano G, Palmerini F, Ravaglia S, Ruiz L, Invernizzi P, et al. (2020) Guillain-Barrè syndrome associated with SARS-CoV-2. N Engl J Med 382: 2574-2576. [Crossref]

59. Franceschi AM, Ahmed O, Giliberto L, Castillo M (2020) Hemorrhagic posterior reversible encephalopathy syndrome as a manifestation of COVID-19 infection. Am J Neuroradiol 41: 1173-1176. [Crossref]

60. Moriguchi T, Harii N, Goto J, Harada D, Sugawara H, et al. (2020) A first case of meningitis/encephalitis associated with SARS-coronavirus-2. Int J Infect Dis 94: 5558. [Crossref]

61. Poyiadji N, Shahin G, Noujaim D, Stone M, Patel S, et al. (2020) COVID-19-associated acute hemorrhagic necrotizing encephalopathy: CT and MRI features. Radiology 296: e119-e120. [Crossref]

62. AHA/ASA Stroke Council Leadership (2020) Temporary emergency guidance to US stroke centers during the coronavirus disease 2019 (COVID-19) pandemic: on behalf of the American Heart Association/American Stroke Association Stroke Council Leadership. Stroke 51: 1910-1912. [Crossref]

63. Faigle R, Butler J, Carhuapoma JR, Johnson B, Zink EK, et al. (2020) Safety trial of low-intensity monitoring after thrombolysis: optimal post TPA-IV monitoring in ischemic stroke (OPTIMIST). Neurohospitalist 10: 11-15. [Crossref]

64. Lechien JR, Chiesa-Estomba CM, De Siati DR, Horoi M, Le Bon SD, et al. (2020) Olfactory and gustatory dysfunctions as a clinical presentation of mild-to-moderate forms of the coronavirus disease (COVID-19): a multicenter European study. Eur Arch Otorhinolaryngol 277: 2251-2261. [Crossref]

65. Hopkins C, Surda P, Kumar N (2020) Presentation of new onset anosmia during the COVID-19 pandemic. Rhinology 58: 295-298. [Crossref]

66. Wu P, Duan F, Luo C, Liu Q, Qu X, et al. (2020) Characteristics of ocular findings of patients with Coronavirus disease 2019 (COVID-19) in Hubei Province, China. JAMA Ophthalmol 138: 575-578. [Crossref]

67. Pan L, Mu M, Yang P, Sun Y, Wang R, et al. (2020) Clinical characteristics of COVID-19 patients with digestive symptoms in Hubei, China: a descriptive, crosssectional, multicenter study. Am J Gastroenterol 115: 766-773. [Crossref]

68. Wong S, Lui R, Sung J (2020) COVID-19 and the digestive system. J Gastroenterol Hepatol 35: 744-748 [Crossref]

69. Redd W, Zhou JC, Hathorn KE, McCarty TR, Bazarbashi AN, et al. (2020) Prevalence and characteristics of gastrointestinal symptoms in patients with SARS-CoV-2 infection in the United States: a multicenter cohort study. Gastroenterology 159: 765-7.e2.

70. Mao R, Qiu Y, He JS, Tan JY, Li XH, et al. (2020) Manifestations and prognosis of gastrointestinal and liver involvement in patients with COVID-19: a systematic review and meta-analysis. Lancet Gastroenterol Hepatol 5: 667-678. [Crossref]

71. Bhatraju PK, Ghassemieh BJ, Nichols M, Kim R, Jerome KR, et al. (2020) COVID-19 in critically ill patients in the Seattle region-case series. $N$ Engl J Med 382: 2012-2022. [Crossref]
72. Phipps MM, Barraza LH, LaSota ED, Sobieszczyk ME, Pereira MR, et al. (2020) Acute liver injury in COVID-19: prevalence and association with clinical outcomes in a large US cohort. Hepatology Acute liver injury in COVID-19: prevalence and association with clinical outcomes in a large US cohort. Hepatology 72: 807-817. [Crossref]

73. Wander P, Epstein M, Bernstein D (2020) COVID-19 presenting as acute hepatitis. Am $J$ Gastroenterol 115: 941-942. [Crossref]

74. Bongiovanni M, Zago T (2020) Acute hepatitis caused by asymptomatic COVID-19 infection. J Infect 82: 4832. [Crossref]

75. Feng Y, Ling Y, Bai T, Xie Y, Huang J, et al. (2020) COVID-19 with differen severities: a multicenter study of clinical features. Am J Respir Crit Care Med 201: 1380-1388. [Crossref]

76. Liang W, Liang H, Ou L, Chen B, Chen A, et al. (2020) Development and validation of a clinical score to predict the occurrence of critical illness in hospitalized patients with COVID-19. JAMA Intern Med 180: 1081-1089. [Crossref]

77. Wang Y, Liu S, Liu H, Li W, Lin F, et al. (2020) SARS-CoV-2 infection of the liver directly contributes to hepatic impairment in patients with COVID-19. J Hepatol 73:807-16. [Crossref]

78. Naicker S, Yang CW, Hwang SJ, Liu BC, Chen JH, et al. (2020) The novel coronavirus 2019 epidemic and kidneys. Kidney Int 97: 824-828. [Crossref]

79. Cheng Y, Luo R, Wang K, Zhang M, Wang Z, et al. (2020) Kidney disease is associated with in-hospital death of patients with COVID-19. Kidney Int 97: 829-838.

80. Hirsch JS, Ng JH, Ross DW, Sharma P, Shah HH, et al. (2020) Acute kidney injury in patients hospitalized with COVID-19. Kidney Int 98: 209-218. [Crossref]

81. Argenziano MG, Bruce SL, Slater CL, Tiao JR, Baldwin MR, et al. (2020) Characterization and clinical course of 1000 patients with coronavirus disease 2019 in New York: retrospective case series. Br Med J 369: m1996.

82. Pei G, Zhang Z, Peng J, Liu L, Zhang C, et al. (2020) Renal involvement and early prognosis in patients with COVID-19 pneumonia. J Am Soc Nephrol 31: 1157-65.

83. Alhazzani W, Moller MH, Arabi YM, Loeb M, Gong MN, et al. (2020) Surviving Sepsis Campaign: guidelines on the management of critically ill adults with coronavirus disease 2019 (COVID-19). Intensive Care Med 28: 1-34. [Crossref]

84. Ronco C, Reis T, Husain-Syed F (2020) Management of acute kidney injury in patients with COVID-19. Lancet Respir Med 8: 738-742. [Crossref]

85. Recalcati S (2020) Cutaneous manifestations in COVID-19: a first perspective. $J$ Eur Acad Dermatol Venereol 34: e212-e213. [Crossref]

86. Jia LL, Kamceva M, Rao SA, Linos E (2020) Cutaneous manifestations of COVID-19: a preliminary review. J Am Acad Dermatol 83: 687-690. [Crossref]

87. Wambier CG, Vano-Galvan S, McCoy J, Gomez-Zubiaur A, Herrera S, et al. (2020) Androgenetic alopecia present in the majority of patients hospitalized with COVID-19: The "Gabrin sign". J Am Acad Dermatol 83: 680-682. [Crossref]

88. Illiano E, Trama F, Costantini E (2020) Could COVID-19 have an impact on male fertility? Andrologia 52: e13654. [Crossref]

89. Abobaker A, Raba A (2020) Does COVID-19 affect male fertility? World J Urol 21 1-2. [Crossref]

90. Pal R, Banerjee M (2020) COVID-19 and the endocrine system: exploring the unexplored. J Endocrinol Invest 43: 1027-1031. [Crossref]

91. Segars J, Katler Q, McQueen D, Kotlyar A, Glenn T, et al. (2020) Prior and nove coronaviruses, Coronavirus Disease 2019 (COVID-19), and human reproduction: what is known? Fertil Steril 113: 1140-1149. [Crossref]

92. Bo HX, Li W, Yang Y, Wang Y, Zhang Q, et al. (2020) Post-traumatic stress symptoms and attitude towards crisis mental health services among clinically stable patients with COVID-19 in China. Psychol Med 27: 1-2. [Crossref]

93. Liu N, Zhang F, Wei C, Jia Y, Shang Z, et al. (2020) Prevalence and predictors of PTSS during COVID-19 outbreak in China hardest-hit areas: gender differences matter. Psychiatry Res 287: 112921. [Crossref]

94. Zhang J, Lu H, Zeng H, Zhang S, Du Q, Jiang T, et al. The differential psychological distress of populations affected by the COVID-19 pandemic. Brain Behav Immun 87: 49-50. [Crossref]

95. Cheng SKW, Tsang JSK, Ku KH, Wong CW, Ng YK (2020) Psychiatric complications in patients with severe acute respiratory syndrome (SARS). Br J Psychiatry 184: 359 360. [Crossref] 
96. Troyer EA, Kohn JN, Hong S (2020) Are we facing a crashing wave of neuropsychiatric sequelae of COVID-19? Neuropsychiatric symptoms and potential immunologic mechanisms. Brain Beh Immun 87: 34-39. [Crossref]
97. Zhou J, Liu L, Xue P, Yang X, Tang X (2020) Mental health response to the COVID-19 outbreak in China. Am J Psychiatry 177: 574-575. [Crossref]

Copyright: $\odot 2021$ Bongiovanni M. This is an open-access article distributed under the terms of the Creative Commons Attribution License, which permits unrestricted use, distribution, and reproduction in any medium, provided the original author and source are credited. 